\title{
Model Optimasi dan Manajemen Risiko pada Saluran Distribusi Rantai Pasok Sayuran Dataran Tinggi Wilayah Sumatera
}

\author{
Optimization and Risk Management Model in Distribution Channels Highlands Vegetables \\ Supply Chain in Agam regency, West Sumatra
}

\author{
Yuviani Kusumawardhani ${ }^{1 *}$, Muhammad Syamsun $^{2 \sharp}$, dan Anggraini Sukmawati ${ }^{2 *}$ \\ ${ }^{1}$ Magister Manajemen, Fakultas Ekonomi dan Manajemen, Institut Pertanian Bogor \\ ${ }^{2}$ Departemen Manajemen, Fakultas Ekonomi dan Manajemen, Institut Pertanian Bogor \\ \#Jl. Kamper, Kampus IPB Darmaga, Bogor 16680
}

\begin{abstract}
ABSTRAK
Sektor pertanian khususnya pada sayuran dataran tinggi dianggap memiliki potensi dan prosepek dalam mendukung diversifikasi pangan sehingga harus memiliki nilai keunggulan yang komparatif. Keunggulan komparatif diperoleh dengan manajemen rantai pasok dan manajemen risiko maka dari itu diperlukan sebuah model optimasi. Namun seringkali dalam kegiatan pertanian sering ditemui risiko yang muncul khususnya pada saluran distribusi rantai pasok. Pengelolaan risiko sangat penting untuk meminimisasi risiko yang merupakan bagian dari manajemen rantai pasok. Tujuan dari penelitian ini adalah (1) menganalisis aliran rantai pasok pada sayuran dataran tinggi Kabupaten Agam, Sumatera Barat dan Kabupaten Karo, Sumatera Utara, (2) mengetahui model optimasi dan manajemen risiko pada saluran distribusi rantai pasok sayuran di daerah dataran tinggi Kabupaten Agam, Sumatera Barat dan Kabupaten Karo, Sumatera Utara, dan (3) menganalisis minimalisasi risiko pada saluran distribusi sayuran dataran tinggi Kabupaten Agam, Sumatera Barat dan Kabupaten Karo, Sumatera Utara. Dalam menganalisis model optimasi dan manajemen risiko digunakan AHP (Analisis Hirarki Proses) dan untuk minimisasi risiko menggunakan ISM (Intrepretive Structural Modelling). Hasil penelitian akan memberikan model optimasi dan manajemen risiko pada saluran distribusi rantai pasok sayuran dataran tinggi agar memiliki nilai yang komparatif.
\end{abstract}

Kata kunci: AHP, ISM, manajemen rantai pasok, model optimisasi, rantai pasok

\section{ABSTRACT}

Agricultural sector, especially in highland vegetables are considered to have the potential and prospects to support diversification. It should have a comparative value advantage. Comparative advantages are obtained with supply chain management and risk management therefore needs a model of optimization. But often the common agricultural activities appear particularly at risk of supply chain distribution channel. Risk management is essential to minimize the risks and part of the supply chain management. The purpose of this study are (1) analyze how the supply chain flow in highland vegetable Agam District, West Sumatra and Karo District, North Sumatra, (2) knowing the model optimization and risk management in the vegetable supply chain distribution channels in Agam District, West Sumatra and Karo District Karo, North Sumatra, and (3) analyze how to minimize risk in the highland vegetable distribution channels in Agam District, West Sumatra and Karo District, North Sumatra. In analyzing the model optimization and risk management in the supply chain distribution channel highland vegetables in Agam District, West Sumatra and Karo District, North Sumatra used AHP (Analysis Hierarchy Process) and for risk minimization used the ISM (Intrepretive Structural Modeling). The results of the study will provide a model optimization and risk management in the supply chain distribution channel highland vegetables in order to have a comparative value.

Key word: AHP, ISM, optimization model, supply chain, supply chain management

\footnotetext{
*) Korespondensi:

Gd. Pascasarjana lt 1 Jl. Raya Pajajaran, Kampus IPB Baranangsiang, Bogor 16144
} 


\section{PENDAHULUAN}

Memasuki era percepatan, yang menyebabkan globalisasi di segala sektor termasuk sektor pertanian dituntut untuk memiliki nilai unggulan yang kompetitif dan komparatif. Sehingga hasil pertanian Indonesia diharapkan dapat bersaing dengan hasil pertanian yang berasal dari luar negeri (impor). Namun, seringkali pada komoditas pertanian memiliki risiko yang cukup tinggi. Maka dari itu, risiko memerlukan pengelolaan yang disebut dengan manajemen risiko. Menurut Djohanputro (2008) Manajemen risiko membantu menurunkan tingkat probabilitas ketidakpastian yang dikuantitaskan dapat menyebabkan kerugian atau kehilangan. Analisis risiko merupakan bagian dari manajemen rantai pasok yang harus dilakukan untuk menghindari atau mengurangi terjadinya kegagalan berbisnis dalam kondisi yang penuh dengan ketidakpastiaan (Marimin dan Maghfiroh, 2010). Keunggulan komparatif selain didapat dengan manajemen risiko juga didapat dengan manajemen rantai pasok. Manajemen rantai pasok merupakan siklus lengkap usaha produksi, mulai dari kegiatan pengelolaan di setiap mata rantai aktivitas produksi hingga siap untuk digunakan oleh pemakai.

Sektor pertanian masih menjadi unggulan bagi suatu negara untuk mensejahterakan Negaranya. Pemerintah Indonesia saat ini berfokus pada sektor pertanian. Hal tersebut dapat dilihat pada tahun 2012, kontribusi sektor pertanian terhadap pendapatan nasional Indonesia berdasarkan besarnya peningkatan nilai Produk Domestik Bruto (PDB), yaitu atas dasar harga berlaku Rp1091,4 triliun meningkat menjadi Rp1190,4 Triliun. Pada tahun 2012 mengalami pertumbuhan 3,97\% (BPS, 2012). Pertanian memiliki peran strategis dalam perekonomian Nasional dan Daerah, bahkan dalam era Reformasi ini diharapkan dapat berperan di garis depan dalam mengatasi krisis Ekonomi. Sektor pertanian di wilayah Sumatera mengalami kenaikan, yaitu $21,19 \%$ menjadi $24,05 \%$. Sumbangan terbesar datang dari Kabupaten Agam dengan sumbangan nilai tambah dari sektor pertanian pada tahun 2013, terdapat PDRB (Produk Domestik Regional Bruto) mencapai 39,72\%, dengan laju pertumbuhan sebesar 7,01\%. Kemudian, Kabupaten Karo, Sumatera Utara juga merupakan wilayah yang sangat potensial sebagai daerah penghasil komo-ditas hortikultura terutama sayuran. Terbentang pada ketinggian 600-1.400 meter di atas permukaan laut dengan topografi tersebut tidak mengherankan jika kabupaten berpenduduk lebih dari 42 ribu jiwa ini masih mengandalkan sektor pertanian sebagai kegiatan ekonomi. Hal ini dibuktikan bahwa 75\% lapangan usaha masyarakat di sana bekerja di sektor pertanian. Sebagai salah satu daerah pusat penghasil sayuran, Kabupaten Karo memiliki kontribusi yang cukup besar dalam kegiatan ekspor sayuran Sumatera Utara yang terus mengalami kenaikan pada akhir tahun 2012.

Sektor pertanian dalam globalisasi harus bersifat kompetitif dan komparatif. Sehingga hasil pertanian Indonesia memiliki nilai (value) yang tidak kalah dengan hasil pertanian negara lainnya. Keunggulan kompetitif diperoleh dengan menerapkan manajemen rantai pasok dan model optimasi dari alternatif rantai yang berada di sepanjang rantai pasok (Hadiguna, 2010). Manajemen rantai pasokan merupakan siklus lengkap usaha produksi, mulai dari kegiatan pengelolaan di setiap mata rantai aktivitas produksi sampai siap untuk digunakan oleh pemakai/user (Christoper, 2006). Sayuran dataran tinggi merupakan tanaman sayuran yang berpotensi dan memiliki prospek yang baik untuk mendukung program diversifikasi pangan dalam rangka mewujudkan ketahanan pangan berkelanjutan. Upaya menyediakan kebutuhan pangan, serta peningkatan kesejahteraan petani, dapat dilakukan dengan upaya peningkatan produksi dan produktifitas. Peningkatan produksi usahatani dapat dilakukan dengan pengembangan dan adopsi teknologi baru serta peningkatan efisiensi suatu usahatani.

Berdasarkan uraian di atas, permasalahan dalam penelitian ini dapat dirumuskan sebagai berikut:

1. Bagaimana aliran rantai pasok sayuran dataran tinggi Kabupaten Agam, Sumatera Barat dan Kabupaten Karo, Sumatera Utara?

2. Bagaimana model optimasi dan manajemen risiko pada saluran distribusi rantai pasok sayuran di daerah dataran tinggi Kabupaten Agam dan Kabupaten Karo, Sumatera Utara?

3. Bagaimana meminimalkan risiko pada saluran distribusi sayuran dataran tinggi di daerah Kabupaten Agam, Sumatera Barat dan Kabupaten Karo, Sumatera Utara?

Sesuai dengan permasalahan yang dirumuskan, maka tujuan dari penelitian ini adalah (1) menganalisis manajemen rantai pasok pada sayuran dataran tinggi Kabupaten Agam, Sumatera Barat dan Kabupaten Karo, Sumatera Utara, (2) mengetahui model optimasi dan manajemen risiko pada saluran distribusi rantai pasok sayuran di daerah dataran tinggi Kabupaten Agam, 
Sumatera Barat dan Kabupaten Karo, Sumatera Utara, dan (3) menganalisis bagaimana meminimisasi risiko pada saluran distribusi sayuran dataran tinggi Kabupaten Agam, Sumatera Barat dan Kabupaten Karo, Sumatera Utara.

\section{METODE PENELITIAN}

Penelitian ini dilakukan di Kabupaten Agam, Sumatera Barat dan Kabupaten Karo, Sumatera Utara secara sengaja (purposive). Penelitian ini dilakukan pada bulan September hingga dengan bulan November 2013. Data yang digunakan dalam penelitian ini adalah data primer dan data sekunder. Pada penelitian ini, data primer diambil dari hasil wawancara, obeservasi, penyebaran kuesioner pada dua pakar yang terkait dengan topik penelitian yaitu penyuluh petani dan ketua Gapoktan (Gabungan Kelompok Tani). Data sekunder diperoleh dari studi pustaka, yaitu buku-buku, literatur, dan penelitian sebelumnya.

Pengolahan dan analisis data yang digunakan adalah analisis deskriptif dan kuantitatif. Analisis deskriptif digunakan untuk memperoleh gambaran mengenai saluran distribusi rantai pasok sayuran dataran tinggi wilayah Kabupaten Agam, Sumatera Barat dan Kabupaten Karo, Sumatera Utara. Sedangkan analisis hirarki proses (AHP) berdasarkan Saaty (1994) dan Interpretive Structural Modelling (ISM) berdasarkan Raessi et al (2013) digunakan untuk menyusun model optimasi dan manajemen risiko pada saluran distribusi rantai pasok sayuran dataran tinggi wilayah Sumatera Barat dan Sumatera Utara.

\section{HASIL DAN PEMBAHASAN}

\section{Analisis Model Distribusi Sayuran Dataran Tinggi pada Kabupaten Agam, Sumatera Barat}

Struktur rantai pasok sayuran dataran tinggi pada umumnya memiliki karakteristik yang sama. Model rantai pasokan sayuran dataran tinggi yang diterapkan pada Gapoktan Kabupaten Agam, Sumatera Barat umumnya mengikuti pola seperti yang ditunjukkan dalam Gambar 1. Aliran struktur rantai pasok sayuran dataran tinggi pada Gapoktan terbagi menjadi tiga rantai, yaitu:

1. Struktur rantai pasok 1

Pada struktur rantai ini, hasil panen yang diproduksi oleh petani dijual kepada pedagang pegepul yang telah melakukan kerjasama sebelumnya dengan petani. Pedagang pe- ngumpul akan menjualkannya ke pasar-pasar tradisional di sekitar wilayah Sumatera Barat, terutama di Kabupaten Agam.

2. Struktur rantai pasok 2

Pada struktur ini, pedagang pengumpul setelah memperoleh hasil panen dari petani akan mendistribusikan atau menjualkan hasil panen ke luar provinsi seperti Jambi, Bengkulu, dan Riau.

3. Struktur rantai pasok 3

Pada struktur ini, petani langsung menjualkan hasil panen sayuran kepada konsumen di pasar-pasar tradisional, khususnya di Kabupaten Agam.

Berdasarkan struktur rantai-rantai pasok tersebut, dapat disimpulkan bahwa anggota rantai pasok memiliki peran yang berbeda-beda antara satu dengan yang lain. Masing-masing anggota dalam model rantai pasok kelompok tani memiliki peran masing-masing dalam setiap aktivitasnya.

\section{Analisis Model Distribusi Sayuran Dataran Tinggi di Kecamatan Brastagi, Sumatera Utara}

Struktur distribusi sayuran dataran tinggi di Indonesia memiliki karakteristik rantai yang berbeda-beda. Perbedaan utama sistem distribusi sayuran terdapat pada jenis sayuran dan kualitas yang dihasilkan. Perbedaan kualitas disebabkan oleh penggunaan bibit yang tidak terstandarisasi oleh petani. Untuk meningkatkan kulitas kentang, maka petani diharapkan dapat menggunakan bibit yang terstandar. Struktur distribusi kentang yang ditemukan pada sentra Kentang Kecamatan Bras-tagi, Sumatera Utara, umumnya mengikuti pola seperti ditunjukkan dalam Gambar 2. Aliran komoditas kentang pada model rantai pasok diatas dibagi menjadi beberapa rantai, sebagai berikut:

1. Struktur rantai pasok 1

Petani menjual barangnya kepada pengumpul yang akan dibawa ke pasar tradisional. Pada penelitian, ditemukan satu orang petani yang juga berprofesi sebagai pengumpul sehingga dapat langsung membawa kentang hasil panennya ke pasar induk Kecamatan Berastagi. Pembeli yang berada di pasar induk Kecamatan Berastagi merupakan pembeli grosiran yang akan menjual lagi produknya ke luar daerah.

2. Struktur rantai pasok 2

Para pengumpul yang ada di Desa Gurusinga juga menjalin kerjasama dengan eksportir yaitu PT Alamanda Sejati Utama. 
Perusahaan ini memasarkan Kentang ke Singapura. Kentang dikirim ke Singapura paling lama dalam waktu seminggu. Kentang dari pengumpul dalam 1 hari langsung ke eksportir. Setelah itu dari eksportir ke Singapura biasanya produk masuk ke gudang selama 2 hari untuk proses pencucian, pemberian grade, dan packaging, dari gudang eksportir ke pelabuhan Belawan memakan waktu 6 hinga 10 jam, dan berada di belawan 1 hari. Eksportir dan pengumpul telah memiliki kontrak kerja sama dalam jangka panjang. Kontrak tersebut memuat jumlah pesanan, kualitas dan harga. Meskipun demikian, pelaksanaan kontrak tersebut belum optimal karena masalah di tingkat petani. Petani terkadang tidak memenuhi jumlah produksi yang disyaratkan karena telah menjual kentangnya ke pihak lain yang menawar lebih tinggi. Akibatnya pengumpul kesulitan memenuhi jumlah produksi yang harus diberikan kepada PT. Alamanda Sejati Utama.

3. Struktur rantai pasok 3

Petani-petani kentang yang ada di Kecamatan Brastagi juga memiliki kerjasama langsung dengan Gudang Eksportir. Kerjasama ini berisi kontrak kuantitas, harga, dan kualitas. Banyak petani yang lebih memilih menjual kentang hasil panennya lebih banyak ke eksportir karena berapapun supply kentang yang petani punya, harganya akan tetap sama. Harga jual di eksportir juga lebih tinggi dari pada harga jual di pasar. Pada struktur distribusi ketiga, kentang dari petani langsung masuk gudang tanpa dilakukan sortasi oleh petani terlebih dahulu. Sortasi dilakukan oleh gudang eksportir. Pihak eksportir biasanya membagi kentang dari petani ke dalam tiga bagian yaitu mini berisi kentang grade $\mathrm{B}$, Medium yaitu kentang grade $\mathrm{A}$, dan terakhir $X L$ dengan kentang grade super. Gudang Eksportir yang ditemukan pada penelitian adalah PT. Alamanda Sejati Utama yang melakukan ekspor khusus untuk perusahaan NTUC Fairprice Cooperative Ltd, Singapura.

4. Struktur Rantai 4

Pada stuktur ini, biasanya kentang yang telah dibawa oleh petani ke Pasar Induk Kecamatan Berastagi ditimbang dan langsung dihargai saat itu juga dengan sistem lelang.
Kentang-kentang yang telah dibeli oleh pembeli grosir akan dijual ke daerah seperti Medan, Aceh, ataupun Jakarta apabila supply kentang di Jakarta tidak dapat memenuhi kebutuhan. Kentang yang dibawa oleh petani hanya dipisahkan antara kentang yang bagus dengan kentang rindilan yang memang tidak laku dijual dan langsung dibuang. Petani mengatakan bahwa belakangan harga kentang anjlok di pasaran karena masuknya kentang dari Bangladesh, India. Akibatnya petani akan membiarkan saja kentang yang seharusnya sudah bisa dipanen sampai harga akan stabil kembali.

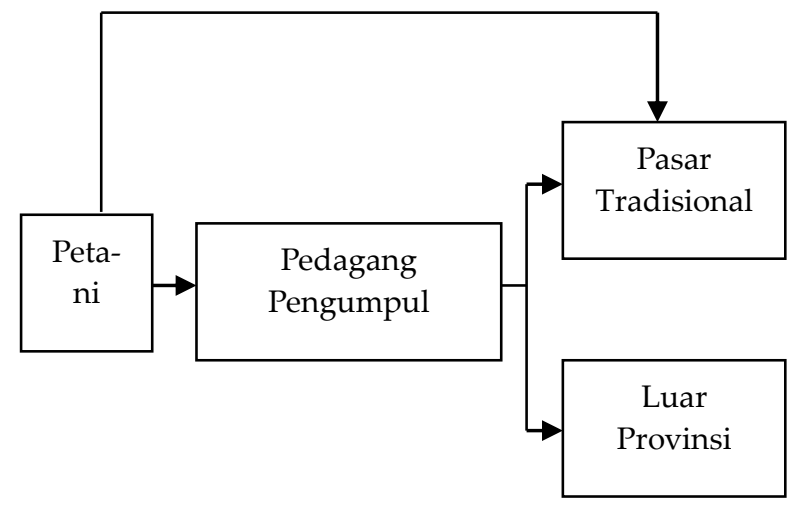

Gambar 1. Struktur rantai pasok sayuran dataran tinggi pada gapoktan (UPT BP4K2P 2013)

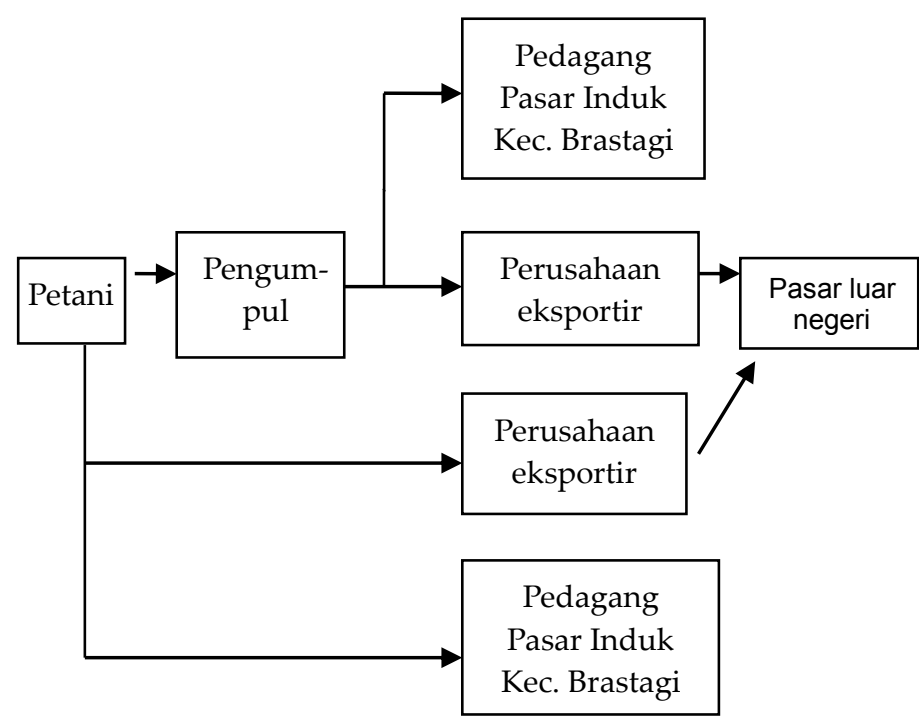

Gambar 2. Model distribusi sayuran dataran tinggi di Kabupaten Karo, Sumatera Utara 


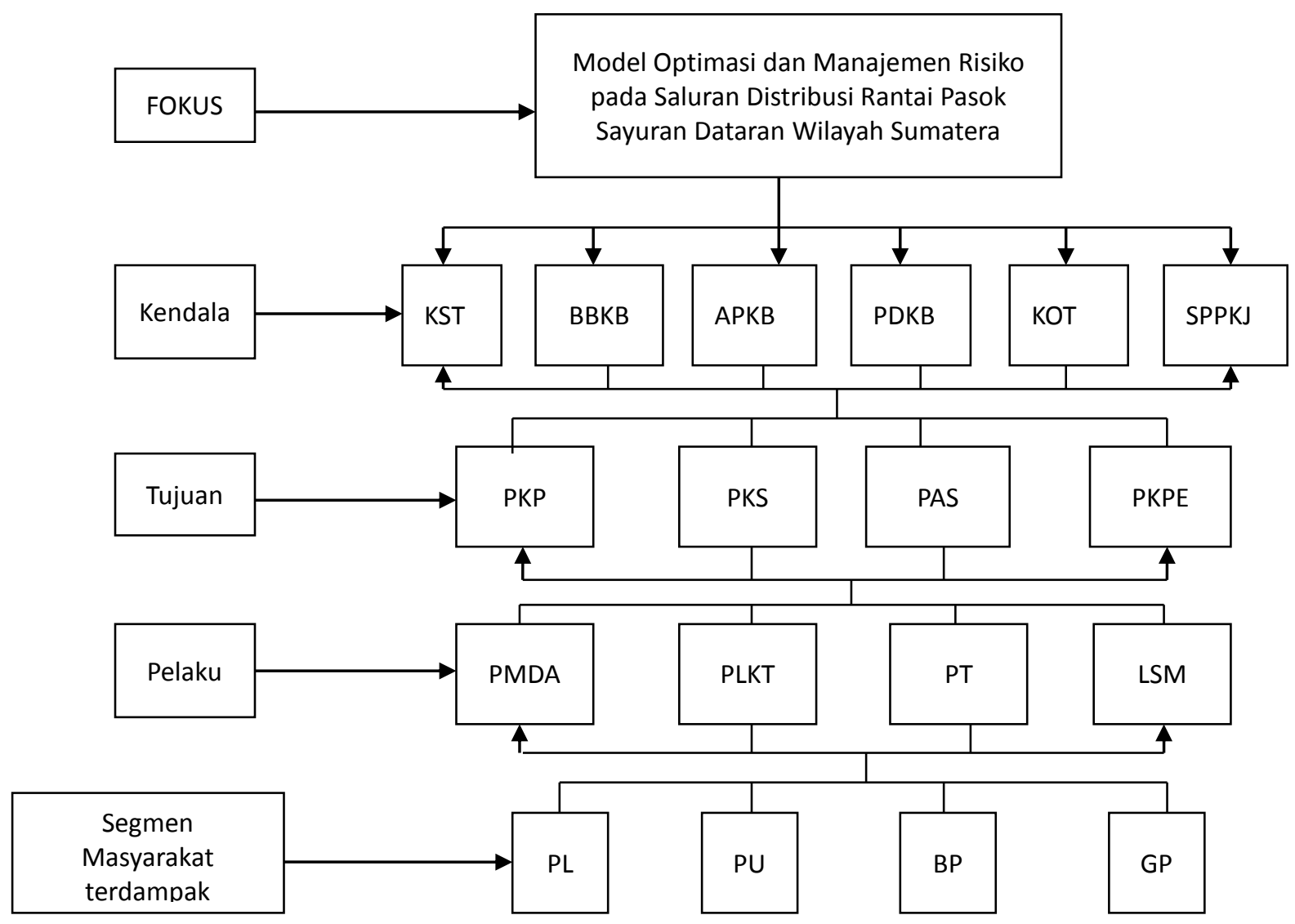

Gambar 3. Struktur hirarki model optimasi dan manajemen risiko pada saluran distribusi rantai pasok sayuran dataran tinggi wilayah Sumatera

Hasil Model Optimasi dan Manajemen Risiko pada Saluran Distribusi Rantai Pasok Sayuran Dataran Tinggi Wilayah Sumatera menggunakan AHP

Berdasarkan hasil kuesioner pakar dengan menggunakan Analytic Hierarchy Process (AHP) diperoleh perbandingan berpasangan antara fokus utama sebagai kontrol dan kendala dan akan dilihat mana yang memiliki pengaruh paling besar. Gambar 3 menunjukkan struktur hirarki pada model optimasi dan manajemen risiko pada saluran distribusi sayuran dataran tinggi di Kabupaten Agam, Sumatera Barat dan Kabupaten Karo, Sumatera Utara. Peubah keterampilan sumber daya manusia (SDM) yang terbatas pada hirarki kendala memiliki bobot yang paling besar yaitu sebesar 0,484. Kemudian pada hirarki kedua, yaitu tujuan yang diperoleh dari perbandingan antara kendala sebagai control utama dan tujuan, diperoleh hasil yang memiliki pengaruh paling besar adalah peningkatan kualitas sayuran dengan bobot 0,399 . Hirarki keempat yang diperoleh dari hasil perbandingan antara tujuan sebagai control dan pelaku, memberikan hasil PEMDA dengan bobot 0,573 sebagai pemberi pengaruh terbesar, dan pada hirarki terakhir yang diperoleh dari hasil perbandingan antara pelaku sebagai kontrol dan segmen masyarakat dan memberikan hasil pemilik lahan sebagai pengaruh terbesar pada hirarki keempat.

Setelah dilakukan penilaian dengan menggunakan AHP, maka disusunlah suatu model optimasi dan manajemen risiko dengan mengkombinasikan yang menjadi prioritas pada setiap hirarki. Berdasarkan hasil AHP, pada hirarki pertama yang paling berpengaruh adalah keterampilan SDM yang terbatas. Pada hirarki kedua yaitu tujuan, yang memberikan pengaruh terbesar adalah peningkatan kualitas sayuran, sehingga untuk mendorong tercapainya model optimasi dan manajemen risiko maka dibutuhkan pelatihan dan pendidikan mengenai keterampilan SDM yang dijalankan oleh PEMDA setempat dengan membuat suatu program dengan mengikutsertakan seluruh pemilik lahan yang dimana pada Kabupaten Agam seluruh pemilik lahan sebagian besar juga sekaligus berprofesi sebagai petani yang tergabung di Gapoktan. Model optimasi dan manajemen risiko yang didapatkan yaitu dalam upaya peningkatan 
kualitas sayuran, PEMDA setempat membuat suatu program mengenai pendidikan dan pelatihan guna membangun keterampilan SDM (petani) yang harus diikuti oleh seluruh pemilik lahan yang sekaligus berprofesi sebagai petani yang bergabung dalam Gapoktan.

\section{Analisis Minimisasi Risiko pada Setiap Elemen dan Sub-elemen}

Setelah dibahas mengenai model optimasi dan manajemen risiko pada saluran distribusi rantai pasok sayuran dataran tinggi wilayah Kabupaten Agam, Sumatera Barat dan Kabupaten Karo Sumatera Utara maka selanjutnya penelitian ini akan membahas mengenai bagaimana memperbaiki suatu sistem pada setiap elemen yang didasarkan pada empat elemen ISM yang terdiri dari kendala, tujuan, pelaku, dan segmen terdampak. Hubungan antar sub-elemen pada setiap elemen akan dibahas untuk meminimisasi risiko dengan memasukkan pula model optimasi dan manajemen risiko yang sebelumnya sudah dibahas menggunakan AHP sehingga akan memaksimalkan kinerja peubah yang berada di setiap elemen.

Unsur yang paling mempengaruhi pada model optimasi dan manajemen risiko saluran distribusi rantai pasok sayuran dataran tinggi berdasarkan Gambar 4 adalah elemen segmen terdampak (4). Peubah yang berada pada top level ini memiliki driving power yang rendah dan ketergantungan antar peubah, yang artinya akan memiliki ketergantungan dengan peubah yang berada di middle level dan bottom level.

Peubah-peubah yang berada pada middle level ini akan memiliki pengaruh yang cukup besar terhadap peubah yang berhubungan dengan peubah terhubung. Pelaku (3), dan tujuan (2) pada middle level hanya dapat dicapai dengan bila melakukan perbaikan pada bottom level terlebih dahulu. Peubah yang berada pada bottom level ini memiliki sifat driver atau pengaruh yang kuat terhadap peubah yang berada di level atasnya sehingga memperbaiki kendala yang ada pada saluran distribusi rantai pasok (1) secara tidak langsung dapat meningkat-kan kinerja model optimasi dan manajemen risiko pada saluran distribusi rantai pasok sayuran dataran tinggi dalam meminimisasi risiko. Model dasar interaksi antar subelemen kendala pada ISM dapat dilihat pada Gambar 4.

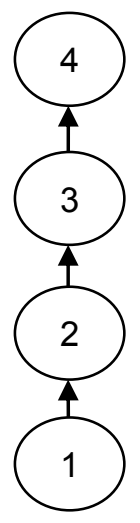

Gambar 4. Model dasar interaksi antar elemen pada ISM

\section{Analisis Minimisasi Risiko Menggunakan ISM} pada Kabupaten Agam, Sumatera Barat

\section{Kendala}

Pada elemen kendala, peubah mutu peralatan pertanian yang kurang baik (3), waktu pengiriman yang tidak tepat waktu (4), jumlah sayuran yang dikirim tidak sesuai (5), dan kenaikan harga BBM mempengaruhi biaya transportasi (7) adalah peubah yang paling mempengaruhhi pada elemen kendala.

Mutu bahan baku yang kurang baik (2), penanganan distribusi pasca panen yang kurang baik (6), dan sistem pembayaran dan pemesanan yang kurang jelas (8) pada middle level hanya dapat dicapai dengan bila melakukan perbaikan pada bottom level terlebih dahulu. Peubah yang berada pada bottom level ini memiliki sifat driver atau pengaruh yang kuat terhadap peubah yang berada di level atasnya. Peubah yang berada pada bottom level adalah keterampilan SDM yang terbatas (1). Peubah ini pada analisis model optimasi dan manajemen risiko yang menggunakan AHP (Analisi Hirarki Proses) merupakan peubah yang diprioritaskan sehingga memperbaiki keterampilan SDM yang terbatas (1) mampu meminimisasi risiko akibat adanya kendalakendala tersebut serta mengoptimalkannya dengan cara PEMDA setempat membuat suatu program mengenai pendidikan dan pelatihan guna membangun keterampilan SDM (petani) yang harus diikuti oleh seluruh pemilik lahan yang sekaligus berprofesi sebagai petani yang tergabung dalam GAPOKTAN sehingga dapat memperkecil timbulnya kendala dan membantu peningkatan kualitas sayuran. Model dasar interaksi antar subelemen kendala pada ISM dapat dilihat pada Gambar 5. 


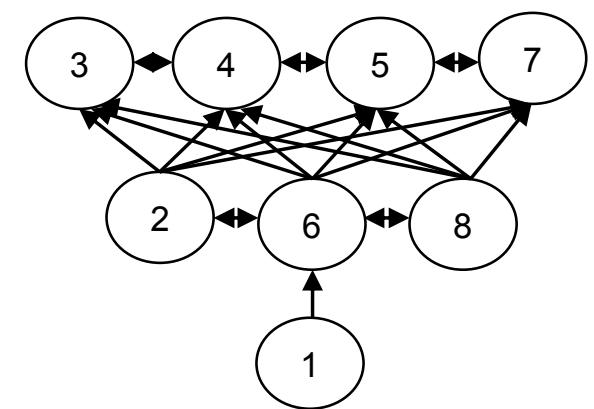

Gambar 5. Model dasar interaksi antar sub-elemen kendala pada ISM

\section{Tujuan}

Pada elemen tujuan, peubah peningkatan kualitas SDM (1) dan kemandirian petani (5) merupakan peubah yang berada pada top level dan paling mempengaruhi elemen tujuan. Peningkatan kesejahteraan petani (4) pada level ini hanya dapat dicapai dengan bila melakukan perbaikan pada bottom level terlebih dahulu. Peubah yang berada pada bottom level ini memiliki sifat driver atau pengaruh yang kuat terhadap peubah yang berada di level atasnya. Peubah pada bottom level adalah peningkatan mutu sayuran (2) dan peningkatan akses ke sumber daya (modal, teknlogi, dan bahan baku (3). Peubah peningkatan mutu sayuran (2) pada analisis model optimasi dan manajemen risiko dengan AHP merupakan peubah yang diprioritaskan sehingga untuk meminimisasi risiko dan mengoptimalkannya menggunakan cara sebagai berikut yaitu PEMDA setempat membuat suatu program mengenai pendidikan dan pelatihan guna membangun keterampilan SDM (petani) yang harus diikuti oleh seluruh pemilik lahan yang sekaligus berprofesi sebagai petani yang tergabung dalam Gapoktan Bersaudara untuk tercapainya peningkatan mutu sayuran (2) dan peningkatan akses ke sumber daya (modal, teknologi, dan bahan baku) (3). Model dasar interaksi antar subelemen tujuan pada ISM dapat dilihat pada Gambar 6.

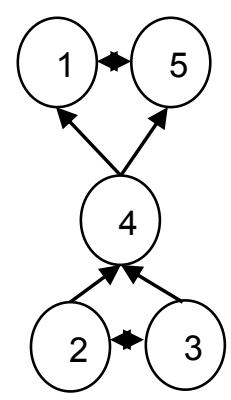

Gambar 6. Model dasar interaksi antar sub elemen tujuan pada ISM

\section{Pelaku}

Pada elemen pelaku, peubah perguruan tinggi (3) dan LSM (5) merupakan peubah yang berada pada top level dan paling mempengaruhi elemen pelaku.

Peubah yang berada pada middle level ini adalah PEMDA (1), perbankan dan lembaga keuangan terkait (2), dan lembaga penjamin keuangan khusus petani (4). Peubah PEMDA (1) pada analisis model optimasi dan maajemen risiko menggunakan AHP merupakan peubah yang diprioritaskan sehingga walaupun peubah-peubah yang berada pada level ini dapat memaksimalkan kontribusinya bila melakukan pembenahan kontribusi pada bottom level terlebih dahulu namun peubah PEMDA yang akan diprioritaskan kontribusinya untuk meminimisasi risiko. Peubah yang berada pada bottom level ini memiliki sifat driver atau pengaruh yang kuat terhadap peubah yang berada di level atasnya sehingga dapat meminimisasi risiko yang ditimbulkan dari kurangnya kontribusi atau peran dari peubahpeubah yang terdapat pada unsur pelaku serta untuk mengoptimalkan upaya peningkatan mutu sayuran, PEMDA setempat membuat suatu program mengenai pendidikan dan pelatihan guna membangun keterampilan SDM (petani) yang harus diikuti oleh seluruh pemilik lahan yang sekaligus berprofesi sebagai petani yang tergabung dalam GAPOKTAN. Memperbaiki kontribusi Lembaga Pendidikan dan Keterampilan (LPK) (6) dalam meningkatkan kualitas petani secara tidak langsung akan memperbaiki kinerja konribusi dari elemen pelaku. Model dasar interaksi antar sub-elemen pelaku pada ISM dapat dilihat pada Gambar 7.

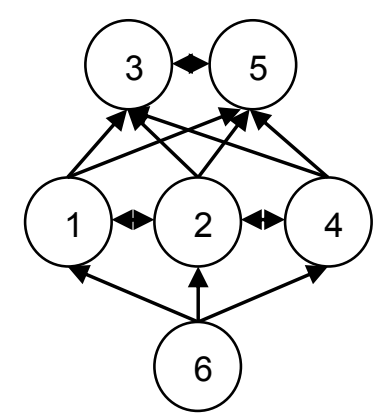

Gambar 7. Model dasar interaksi antar sub elemen pelaku pada ISM

\section{Segmen Masyarakat Terdampak}

Pada elemen segmen masyarakat terdampak, peubah pengusaha atau UKM di sektor informal (4) merupakan peubah yang berada pada 
top level dan paling mempengaruhi unsur segmen masyarakat terdampak.

Peubah pada bottom level ini adalah PEMDA (1), pemilik lahan (2), pengusaha/UKM di sector pertanian (3), dan buruh tani (5). Peubah pemilik lahan (2) merupakan peubah yang diprioritaskan beradasarkan analisis model optimasi dan manajemen risiko menggunakan AHP sehingga peubah pemilik lahan (2) diprioritaskan untuk mendapatkan dampak yang lebih besar walaupun pada level ini untuk merasakan dampak yang besar harus memberikan dampak terlebih dulu pada peubah di bottom level. Peubah yang berada pada bottom level ini memiliki sifat driver atau pengaruh yang kuat terhadap peubah yang berada di level atasnya sehingga dapat meminimisasi risiko penyimpangan segmen terdampak selain yang ada pada elemen segmen masyarakat terdampak serta mengoptimalkan upaya peningkatan kualitas sayuran, PEMDA setempat membuat suatu program mengenai pendidikan dan pelatihan guna membangun keterampilan SDM (petani) yang harus diikuti oleh seluruh pemilik lahan yang sekaligus berprofesi sebagai petani yang bergabung dalam GAPOKTAN. Fokus pada GAPOKTAN (6) merupakan awal yang baik apabila untuk memperluas dampak yang akan dirasakan oleh masyarakat. Model dasar interaksi antar sub-elemen segmen masyarakat terdampak pada ISM dapat dilihat pada Gambar 8.

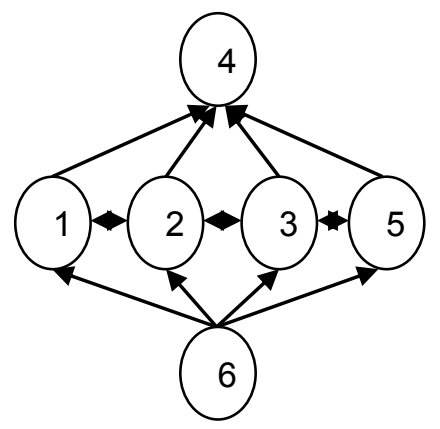

Gambar 8. Model dasar interaksi antar sub-elemen segmen masyarakat terdampak pada ISM

Analisis Minimisasi Risiko Menggunakan ISM pada Kabupaten Karo, Sumatera Utara

\section{Kendala}

Berdasarkan hasil studi pada elemen kendala di Kecamatan Brastagi, Sumatera Utara, peubah mutu peralatan pertanian yang kurang baik (3), waktu pengiriman yang tidak tepat waktu (4), jumlah sayuran yang dikirim tidak sesuai (5), kenaikan harga BBM mempengaruhi biaya transportasi (7), dan sistem pembayaran dan pemesanan yang kurang jelas (8) adalah peubah yang paling mempengaruhi pada elemen kendala.

Mutu bahan baku yang kurang baik (2), keterampilan SDM yang terbatas (1) adalah peubah yang berada pada middle level. Peubah keterampilan SDM yang terbatas pada analisis model optimasi dan manajemen risiko yang menggunakan AHP merupakan peubah yang diprioritaskan sehingga dengan memperbaiki keterampilan SDM yang terbatas (1) mampu meminimisasi risiko akibat adanya kendalakendala tersebut serta mengoptimalkannya dengan cara PEMDA setempat membuat suatu program mengenai pendidikan dan pelatihan guna membangun keterampilan SDM (petani) yang harus diikuti oleh seluruh pemilik lahan yang sekaligus berprofesi sebagai petani yang tergabung dalam GAPOKTAN sehingga dapat memperkecil timbulnya kendala dan membantu peningkatan kualitas sayuran. Kemudian, peubah pada middle level hanya dapat dimaksimalkan kinerjanya dengan bila melakukan perbaikan pada bottom level terlebih dahulu. Peubah yang berada pada bottom level ini memiliki sifat driver atau pengaruh yang kuat terhadap peubah yang berada di level atasnya. Peubah yang berada pada bottom level adalah penanganan distribusi pasca panen yang kurang baik (6). Memperbaiki penanganan distribusi pasca panen yang kurang baik terlebih dulu dapat membantu kinerja peubah-peubah yang berada diatasnya ntuk menjadi lebih baik. Model dasar interaksi antar sub-elemen kendala pada ISM dapat dilihat pada Gambar 9.

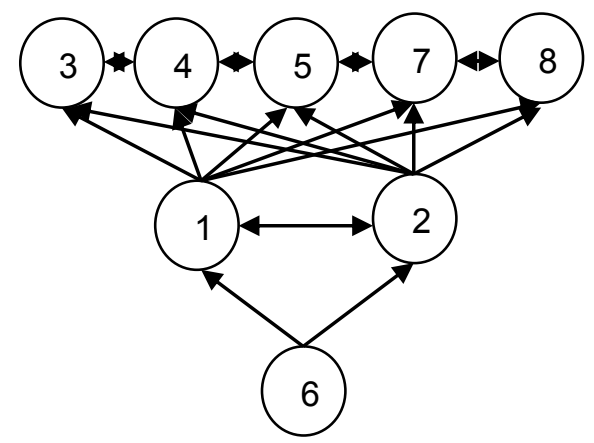

Gambar 9. Model dasar interaksi antar sub-elemen kendala pada ISM

\section{Tujuan}

Pada elemen tujuan, peubah peningkatan kualitas SDM (1), peningkatan akses ke sumber daya (modal, teknlogi, dan bahan baku) (3), Peningkatan kesejahteraan petani (4) dan kemandirian petani (5) merupakan peubah yang 
berada pada top level dan paling mempengaruhi elemen tujuan.

Peubah pada bottom level adalah peningkatan kualitas sayuran (2). Peubah peningkatan kualitas sayuran (2) pada analisis model optimasi dan manajemen risiko dengan menggunakan AHP merupakan peubah yang diprioritaskan sehingga untuk meminimisasi risiko dan mengoptimalkannya menggunakan cara sebagai berikut yaitu PEMDA setempat membuat suatu program mengenai pendidikan dan pelatihan guna membangun keterampilan SDM (petani) yang harus diikuti oleh seluruh pemilik lahan yang sekaligus berprofesi sebagai petani yang tergabung dalam Gapoktan untuk tercapainya peningkatan mutu sayuran (2). Sehingga dengan meningkatkan kualitas sayuran yang disertai oleh model optimasi dengan meminimisasi resiko maka secara tidak langsung memperbaiki kinerja sistem pada elemen tujuan secara keseluruhan. Model dasar interaksi antar sub-elemen tujuan pada ISM dapat dilihat pada Gambar 10.

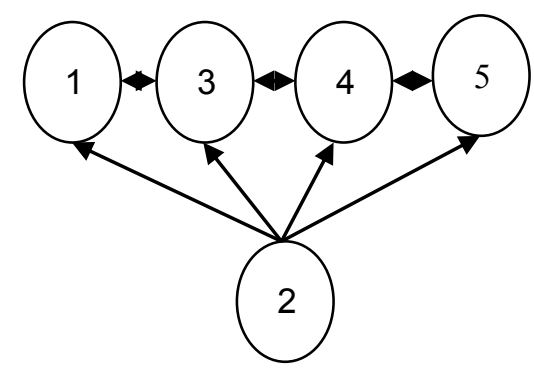

Gambar 10. Model dasar interaksi antar sub-elemen tujuan pada ISM

\section{Pelaku}

Pada elemen pelaku, PEMDA (1), adalah perbankan dan lembaga keuangan terkait (2), peubah perguruan tinggi (3) lembaga penjamin keuangan khusus petani (4), memperbaiki kontribusi Lembaga Pendidikan dan Keterampilan (LPK) (6) merupakan peubah yang berada pada top level dan paling mempengaruhi elemen pelaku. Berdasarkan analisis model optimasi dan maajemen risiko menggunakan AHP peubah PEMDA (1) merupakan peubah yang diprioritaskan sehingga peubah-peubah yang berada pada level ini dapat mengoptimalkan kontribusinya dengan model optimasi sebagai berikut PEMDA setempat membuat suatu program mengenai pendidikan dan pelatihan guna membangun keterampilan SDM (petani) yang harus diikuti oleh seluruh pemilik lahan yang sekaligus berprofesi sebagai petani yang tergabung dalam
Gapoktan untuk tercapainya peningkatan kualitas sayuran sehingga dapat meminimisasi terjadinya resiko yang terjadi, seperti risiko kurangnya kontribusi dari pelaku pada elemen ini.

Peubah yang berada pada bottom level adalah peubah LSM (5), peubah ini memiliki sifat driver atau pengaruh yang kuat terhadap peubah yang berada di level atasnya sehingga dengan diperbaikinya kontribusi dari LSM atau memaksimalkan kontribusi LSM pada upaya peningkatan kualitas petani secara tidak langsung akan memperbaiki kinerja konribusi dari elemen pelaku. Model dasar interaksi antar subelemen pelaku pada ISM dapat dilihat pada Gambar 11.

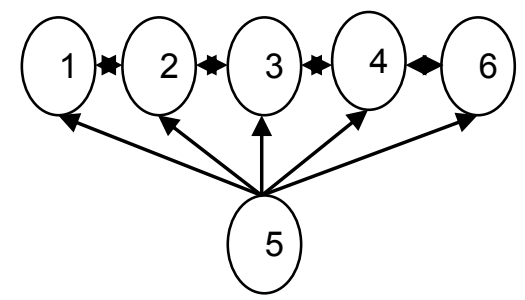

Gambar 11. Model dasar interaksi antar sub elemen pelaku pada ISM

\section{Segmen Masyarakat Terdampak}

Pada elemen segmen masyarakat terdampak, peubah PEMDA (1), pemilik lahan (2), pengusaha/UKM di sektor pertanian (3), pengusaha atau UKM di sektor informal (4), dan Gapoktan (6) merupakan peubah yang berada pada top level dan paling mempengaruhi elemen segmen masyarakat terdampak.

Peubah pemilik lahan (2) merupakan peubah yang diprioritaskan beradasarkan analisis model optimasi dan manajemen risiko menggunakan AHP sehingga peubah pemilik lahan (2) diprioritaskan untuk memaksimalkan dampak yang dirasakan oleh masyarakat. Namun pada upaya memaksimalkan dampak pada segmen masyarakat terdapat risiko penyimpangan segmen terdampak selain yang ada pada elemen segmen masyarakat terdampak, oleh karena itu perlu model optimasi yaitu dalam upaya peningkatan kualitas sayuran, PEMDA setempat membuat suatu program mengenai pendidikan dan pelatihan guna membangun keterampilan SDM (petani) yang harus diikuti oleh seluruh pemilik lahan yang sekaligus berprofesi sebagai petani yang bergabung dalam Gapoktan.

Peubah pada bottom level ini adalah dan buruh tani (5). Peubah yang berada pada bottom level ini memiliki sifat driver atau pengaruh yang kuat terhadap peubah yang berada di level 
atasnya sehingga dapat. Fokus pada merupakan awal yang baik apabila untuk memperluas dampak yang akan dirasakan oleh masyarakat. Model dasar interaksi antar sub-elemen segmen masyarakat terdampak pada ISM dapat dilihat pada Gambar 12.

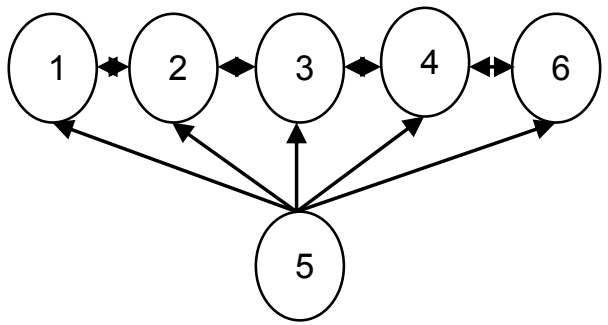

Gambar 12. Model dasar interaksi antar sub elemen segmen masyarakat

\section{KESIMPULAN}

Sistem saluran distribusi rantai pasok sayuran dataran tinggi di Kabupaten Agam, Sumatera Barat terdiri dari tiga model saluran distribusi, yang pertama berhulu di petani kemudian pengumpul dan berakhir di pasar tradisonal. Kedua petani memberikan hasil panen sayuran dataran tinggi ke pengumpul kemudian pengumpul membawanya ke pasar luar provinsi. Ketiga, petani membawa hasil panen sayurnya sendiri langsung ke pasar kemudian mereka menjual di pasar tradisonal setempat. Sedangkan sistem saluran distribusi di Kecamatan Brastagi, Kabupaten Karo, Sumatera Utara terdiri dari empat model saluran distribusi, yang pertama berhulu di petani kemudian pengumpul dan berakhir di pedagang pasar induk Kecamatan Brastagi. Kedua, petani memberikan hasil panen pada pengumpul kemudian, pengumpul menyerahkannya pada perusahaan eksportir dan terakhir perusahaan eksportir membawa hasil panen ke pasar luar negeri seperti Singapura. Ketiga, petani memberikan langsung hasil panennya pada perusahaan eksportir kemudian perusahaan eksportir membawanya ke pasar luar negeri. Keempat, petani secara langsung membawa hasil panennya ke pasar induk Kecamatan Brastagi, Kabupaten Karo, Sumatera Utara.

Seiring semakin terbukanya persaingan global, mengakibatkan semakin banyaknya persaingan antar komoditas dan produk dari negaranegara lain, termasuk produk-produk pertanian. Oleh karena itu diperlukan suatu cara untuk meningkatkan mutu keterampilan petani dalam aktivitas saluran distribusi rantai pasok sayuran dataran tinggi. Terdapat beberapa kendala dan kurangnya kontribusi dari beberapa pelaku dalam saluran distribusi rantai pasok, sehingga diperlukan suatu model optimasi dan manajemen risiko pada saluran distribusi rantai pasok sayuran dataran tinggi. Model ini dibuat bertujuan untuk meningkatkan kualitas sayuran dengan cara PEMDA membuat suatu program mengenai pendidikan dan pelatihan guna membangun keterampilan SDM (petani) yang harus diikuti oleh seluruh pemilik lahan yang sebagian besar berprofesi sebagai petani yang tergabung dalam Gapoktan. Kemudian upaya meminimisasi risiko dengan memasukkan model optimasi dan peubahpeubah yang menjadi prioritas setiap hirarki pada AHP ke dalam empat elemen ISM yaitu elemen kendala, tujuan, pelaku, dan segmen masyarakat terdampak yang mampu membantu membenahi sistem yang ada pada setiap elemen sehingga dapat meningkatkan kinerja setiap elemen dengan memperbaiki peubah-peubah yang berada pada bottom level terlebih dahulu dan memprioritaskan peubah-peubah yang berdasar-kan analisis AHP yang nantinya akan berdampak pada level yang berada diatasnya.

\section{DAFTAR PUSTAKA}

Anatan, L dan L. Ellitan. 2008. Supply Chain Management Teori Dan Aplikasi. Bandung: Alfabeta.

Astuti R. 2012. Pengembangan Rantai Pasok Buah Manggis di Kabupaten Bogor, Jawa Barat [disertasi]. Bogor (ID): Insititut Pertanian Bogor.

[BPS] Badan Pusat Statistik. 2012. Pertumbuhan Ekonomi Indonesia Tahun 2012 [Internet]. [diunduh 2013 Septem 15]. Tersedia pada: http://bps.go.id.

Chandramowli S., Transue M., Felder, FA. 2011. Analysis of barriers to development in landfill communities using interpretive structural modeling. Habitat International 35: 246-253.

Christopher ST. 2006. Perspectives in Supply Chain Risk Management.Int. J. Production Economics. 103 (2006) 451-488.

Djohanputro B. 2008. Manajemen Risiko Korporat Terintegrasi. Jakarta (ID): PPM.

Hadiguna R. 2010. Perancangan Sistem Penunjang Keputusan Rantai Pasokan dan Penilaian Risiko Mutu Pada Agroindustri Kelapa 
Sawit Kasar [disertasi]. Bogor (ID): Institut Pertanian Bogor.

Haming, M dan M. Nurnajamuddin. 2007. Manajemen Produksi Modern Operasi Manufaktur dan Jasa Buku 2. Jakarta: PT Bumi Aksara

Indrawanto C. 2009. Kajian Pengembangan Industri Akar Wangi (Vetiveria zizanoides L.) menggunakan Interpretive Structural Modeling. Bogor. Informatika Pertanian. 18(1):4-6.

Ma'Arif M, Tanjung H. 2003. Manajemen Operasi. Jakarta (ID): PT Grasindo.

Marimin, Maghfirof N. 2010. Aplikasi Teknik Pengambilan KeputusanDalam Manajemen Rantai Pasok. Bogor (ID): IPB Pr.

Muslich M. 2007. Manajemen Risiko Operasional Teori dan Praktek. Jakarta (ID): PT Bumi Aksara.

Prawirosentono S. 2007. Manajemen Operasi Analisis dan Studi Kasus Edisi ke-4. Jakarta (ID): PT Bumi Aksara.

Raessi R, Dastranj M, Mohammadi S, Rasouli E. 2013. Understanding the Interactions among The Barriers to Entrepreneurship Using Interpretive Structural Modelling. International Journal of Business and Management, 8(13): 56-69

Rajesh A, Nikhil D, Vivek S. 2013. Interpretive Structural Modelling (ISM) approach: An Overview. Research Journal of Management Sciences. 2(2), 3-8.
Rajesh AK, Satish VB. 2012. Interpretive Structural Modeling Based Approach for Adopting CPFR in Indian Industries. International Journal of Research Commerce, IT, and Management. 2(2):136-139.

Rajesh K Singh. 2011. Developing the framework for coordination in supply chain of SMEs. Business Process Management Journal. 17(4): 619-638.doi: 10.1108/14637151111149456

Saaty TL. 1994, Fundamentals of Decision Making and Priority Theory with The Analytic Hierarchy Process, RWS Publications, USA.

Shahabadkar P, Hebbal SS, Prashant S. 2012. Deployment of Interpretive Structural Modeling Methodology in Supply Chain. International Journal of Industrial Engineering \& Production Research. 23(3): 196-202.

Siagiaan YM. 2005. Aplikasi Supply Chain Management dalam Dunia Bisnis. Jakarta (ID): PT Grasindo.

Tunggal AW. 2009. Supply Chain Management (Manajemen Rantai Pasokan). Jakarta (ID): Harvarindo.

[UPT BP4K2P] Unit Pelaksana Teknis Balai Pelaksana Penyuluhan Pertanian, Perikanan, Kehutanan dan Ketahanan Pangan Kecamatan Baso, Kabupaten Agam. 2012. Program Penyuluhan Pertanian. Agam (ID).

Wang G, Wang Y, Zhao T. 2008. Analysis of interactions among barriers to energy saving in China. Energy Policy. 36: 18791889. 